\title{
El rol de los elementos no-racionales en la construcción democrática
}

María de los Ángeles Yannuzzi

María de los Ángeles Yannuzzi es Profesora e Investigadora en la Universidad Nacional de Rosario.

e-mail: yannuzzi@ciudad.com.ar

\section{Resumen}

Catalogados como formas falsas de conocimiento, el racionalismo y el positivismo decimonónico no hicieron más que ignorar el rol que los sentimientos, las creencias y los mitos cumplieron en el ámbito de la política. Fue recién con la conformación de la democracia de masas que se descubre que las acciones de los hombres se asientan sobre un substrato inicial de creencias. Sin embargo, si bien ligados a temas tales como la ideología, la legitimidad o, incluso, la transformación de la sociedad, su tratamiento a lo largo de la teoría política contemporánea muchas veces ha visto velado el rol cohesionador y movilizador que realmente les cabe.
Una versión preliminar del presente trabajo fue presentada en el IX Congreso Nacional de Ciencia Política de la Sociedad Argentina de Análisis Político realizado en Santa Fe del 19 al 22 de agosto de 2009.

\section{Summary}

Classified as false forms of knowledge, rationalism and nineteenth century positivism ignored the role that feelings, beliefs and myths accomplished in the political dimension. It was with mass democracy that it was discovered that human actions are based on a first substratum of beliefs. However, though related to issues such as ideology, legitimacy or even society transformation, their treatment along contemporary political theory has hidden much of the time the cohesive and mobilizing role they play. 